\title{
Terpene constituents of the aerial parts, phenolic content, antibacterial potential, free radical scavenging and antioxidant activity of Callistemon citrinus (Curtis) Skeels (Myrtaceae) from Eastern Cape Province of South Africa
}

Rotimi A. Larayetan ${ }^{1,2^{*}}$, Omobola O. Okoh ${ }^{1}$, Alexander Sadimenko ${ }^{1}$ and Anthony I. Okoh ${ }^{3,4}$

\begin{abstract}
Background: Volatile oil from aromatic plants has been used by ancient Egyptians in embalming for the inhibition of bacterial growth and prevention of decay, Callistemon citrinus is used in traditional therapies for the treatment of bronchitis, cough, inflammation and as an antimicrobial herbs. This study examines the essential constituents of the volatile oils obtained from the aerial parts of the plant as well as its antioxidant activity, free radical scavenging, phenolic content and the antibacterial potential of the oils.

Methods: A portion of $500 \mathrm{~g}, 250 \mathrm{~g}$ and $150 \mathrm{~g}$ of the leaves, flowers and stems of this plant respectively were subjected to hydro-distillation process for three hours. The oils collected from the various plant parts were immediately subjected to GC-MS analysis. The overall phenolic content of the leaves oil, radical scavenging, antibacterial action and antioxidant activities of the essential oils of both the leaves and flowers of Callistemon citrinus were determined using standard methods, with free radical DPPH and ABTS as a reference antioxidant.

Results: Analyses of the three oils revealed a total of twenty-six components for the leaves oil representing 96.84\% of the total oil composition, forty-one components for the flowers oil accounting for $98.92 \%$ of the whole composition and ten components for the stem oil amounting to $99.98 \%$ of the entire oil constituents. The dominant compounds in the leaves oil were eucalyptol (48.98\%) and a-terpineol (8.01\%), while a-eudesmol (12.93\%), caryophyllene (11.89\%), (-)-bornyl-acetate (10.02\%) and eucalyptol (8.11\%) were the main constituents of the flowers oil. In the same vein, the leading constituents in the stems oil were eucalyptol (56.00\%) and a-pinene (31.03\%). The antioxidant capacities of both the leaves and flowers oils of the plant were evaluated and their $\mathrm{IC}_{50}$ were (1.49 and 1.13) for DPPH and (0.14 and 0.03) for ABTS assay respectively. The antibacterial activities of the oils from the (leaves and flowers) were also examined and were found to have wide range of activities against the bacterial strains used in this study.

Conclusion: Observations drawn from this experiment shows clearly that the leaves and flowers of Callistemon citrinus possess phenolic compounds and cyclic ether of several pharmacological behaviors.
\end{abstract}

Keywords: Volatile oil, Hydro distillation, Antimicrobial, Antioxidant, DPPH, ABTS, Opc

\footnotetext{
* Correspondence: timlarayetan@gmail.com

${ }^{1}$ Department of Pure and Applied Chemistry, University of Fort Hare, Alice

5700 , South Africa

${ }^{2}$ Chemistry Department, Kogi State University, Anyigba, Kogi, Nigeria

Full list of author information is available at the end of the article
} 


\section{Background}

Volatile oils are complex and of natural origin having a strong odour, they are usually formed from odoriferous medicinal plants, apart from volatile oil, aromatic plants possess phenolic compounds with numerous pharmacological activities. The study of the constituents of therapeutic plants is of immense significance needed for the production of novel drugs [1].

The genus Callistemon belongs to the Myrtaceae family and consists of about thirty-four varieties, 'Callistemon' means Anther beauty [2], it is an evergreen shrubs and small tree with lanceolate and aromatic leaves which are prevalent to Australia although a number of them have been brought to other regions like USA [3] and Africa [4]. Callistemon is referred to as 'bottle brush' owing to its cylindrical brush like flowers resembling the conventional bottle brush. The brilliant red flowers spikes of Callistemon citrinus are extremely rich in nectar and as a result attract many birds and insects $[5,6]$. Callistemon had been used as anticough and antibronchitis in folkloric medicine. The antiphylococcal, nematocidal, larvicidal, pupicidal, antithrombotic and antioxidant activities of the class Callistemon species and also the antimicrobial properties of their volatile oils had been widely reported [7].

Callistemon citrinus (Curtis) Skeels is a flowering plant and the most commonly cultivated class of the 34 species of Callistemon genus [8]. It is a shrub with a height of about $7.5 \mathrm{~m}$ tall, having beautiful red flowers with red dark anthers. This plant is used to treat gastrointestinal disorder, pain and infectious diseases caused by bacteria, fungi, virus and other pathogens [9]. The plant is used traditionally in India to combat respiratory conditions like cough, bronchitis and also as insecticides, while its volatile oil is employed as an antimicrobial herbal drug $[10,11]$. The leaves are also known for its anti-inflammatory, fungitoxicity; antinociceptive activities [12, 13]. Callistemon species are usually grown as decorative plants in houses, offices, streets, and garden area due to its bright red flowers spikes $[5,6]$. The essential oil of the leaves has been extensively studied globally by researchers. Eucalyptol (a cyclic monoterpenoid ether) has been found to be the dominant constituents of this plant with various degrees of pharmacological effects and hence it is used as a marker for medicinal essential oil classification [14]. Its medicinal and odoriferous properties are also very unique $[15,16]$. Essential oils of the aromatic plants have been used by ancient Egyptians in embalming for the inhibition of bacterial growth and decay. There is a strong in-vitro proof that shows that volatile oils can be active antibacterial agents against several spectrums of pathogenic bacterial strains [17-19], however, there is dearth of information on the chemical profile of the volatile oils of Callistemon citrinus obtained from the flowers and stems, thus the present study was undertaken with the aim of investigating the essential constituents of its volatile oil as well as its antioxidant, free radical scavenging, phenolic content and the antibacterial potentials of both the leaves and flowers of Callistemon citrinus respectively from Eastern Cape Province of South Africa.

\section{Methods}

\section{Plant collection}

Fresh leaves with flowers were collected in March 2016, from the vicinity of the University of Fort Hare (UFH) Eastern Cape Province of South Africa, the plant was identified by Dr. Meyikeso of the Department of Botany and voucher sample (Larayetan 1) was kept in the Giffen herbarium (UFH), University of Fort Hare, South Africa for record purpose.

\section{Microbial strains}

Pure isolates of Aeromonas hydrophila (ACC), Escherichia coli (ATCC 35150), Salmonella typhi (ACC), Listeria monocytogenes (ACC), Vibro alginolyticus (DSM 2171), Staphylococcal enteritis (ACC) and Staphylococcus aureus $(A C C)$ were obtained from Biochemistry and Microbiology Department of the university. All the cultures were maintained on nutrient agar for further use.

\section{Reagents used}

2, 2-azinobis-(3-ethylbenzothiazolin-6-sulfonic acid) diammonium, 2, 2-diphenyl-1-picrylhydrazyl (DPPH) and Potassium persulfate (PPS) were bought from SigmaAldrich (St Louis, USA) for this study. All other analytical grade reagents used were sourced from Merck (Germany).

\section{Quantification of total phenolic content}

The overall phenolic content of the leaves volatile oil was determined by the procedure of Folin-Ciocateau. Exactly $1 \mathrm{~mL}$ of Folin-Ciocateau reagent was mixed with $1 \mathrm{~mL}$ aliquot of the volatile oil and $46 \mathrm{~mL}$ of distilled water. After $3 \mathrm{~min} 3 \mathrm{~mL}$ of $(2 \% \mathrm{w} / v)$ of $\mathrm{Na}_{2} \mathrm{CO}_{3}$ solution was added to the mixture shaken and incubated for two hours in the dark. Absorbance of the resulting mixture was taken on a UV-visible spectrophotometer at $760 \mathrm{~nm}$ against the blank and the overall phenolic content was presented as gallic acid equivalent (GAE) in $\mu \mathrm{gmg}^{-1}$ [20].

\section{In-vitro antioxidant action DPPH assay}

The radical scavenging and antioxidant activities of the oils from both the leaves and flowers of the plant were evaluated against the free radical DPPH. Five different concentrations $\left(0.025-0.40 \mathrm{mgmL}^{-1}\right)$ of the oils and commercial antioxidants ( $\beta$-carotene \& Vitamin $C$ ) were incubated with a DMSO solution of DPPH for about $30 \mathrm{~min}$ at ambient temperature in the dark. The mixture 
Table 1 Fractional compositions of constituents of the leaves flowers and stems oil of Callistemon citrinus

\begin{tabular}{|c|c|}
\hline $\begin{array}{l}\text { Retention } \\
\text { Time (Min) }\end{array}$ & Constituents \\
\hline 3.43 & Isopentyl Acetate \\
\hline 3.89 & $\beta$-Thujene \\
\hline 3.97 & a-Pinene \\
\hline 3.98 & 1R-a-Pinene \\
\hline 4.12 & Camphene \\
\hline 4.25 & Vinyl Amyl Carbinol \\
\hline 4.29 & $\beta$-Phellandrene \\
\hline 4.34 & $\beta$-Pinene \\
\hline 4.52 & Heptane-3,4-dimethyl \\
\hline 4.69 & o-Cymene \\
\hline 4.73 & Limonene \\
\hline 4.77 & Eucalyptol \\
\hline 4.97 & Y-Terpinene \\
\hline 5.21 & 3-Carene \\
\hline 5.23 & $\beta$-linalool \\
\hline 5.44 & a-Fenchol \\
\hline 5.67 & Pinocarveol \\
\hline 5.73 & (+)-2-Bornanone \\
\hline 5.76 & Camphenilanol \\
\hline 5.85 & Pinocarvone \\
\hline 5.88 & Borneol \\
\hline 5.94 & Terpinen-4-ol \\
\hline 6.03 & a-Terpineol \\
\hline 6.09 & Myrtenol \\
\hline 6.22 & Cis-Carveol \\
\hline 6.23 & (+)-Camphene \\
\hline 6.30 & Cis-p-metha-1(7), 8-diene-2-ol \\
\hline 6.42 & Geraniol \\
\hline 6.75 & (-)-Bornylacetate \\
\hline 7.11 & Trans -2-acetoxyl-1,8-cineole \\
\hline 7.23 & 4-Carene \\
\hline 7.42 & Copaene \\
\hline 7.77 & Caryophyllene \\
\hline 7.89 & Aromadendrene \\
\hline 7.93 & a-Gurjinene \\
\hline 7.98 & Humulene \\
\hline 8.03 & Alloaromadendrene \\
\hline 8.08 & a-Elemene \\
\hline 8.16 & a-Farnesene \\
\hline 8.25 & Bicyclogermacrene \\
\hline 8.36 & $(+)$ - $\delta$-Cadinene \\
\hline 8.52 & Elemol \\
\hline
\end{tabular}

Table 1 Fractional compositions of constituents of the leaves flowers and stems oil of Callistemon citrinus (Continued)

\begin{tabular}{|c|c|c|c|c|}
\hline 8.65 & (+)-Valencene & - & 0.37 & - \\
\hline 8.76 & Spathulenol & 0.19 & 3.16 & 1.10 \\
\hline 8.80 & $(-)-G l o b u l o l$ & 0.39 & - & 0.65 \\
\hline 8.82 & (+)-Ledene & - & 2.33 & - \\
\hline 8.86 & $\gamma$-Gurjinene & 0.20 & - & - \\
\hline 8.87 & (+)-Viridiflorol & - & 0.49 & - \\
\hline 8.91 & Rosifoliol & - & 0.50 & - \\
\hline 8.96 & $\begin{array}{l}\text { Benzoic acid, 3,4-dimethoxy, } \\
\text { methyl Ester }\end{array}$ & 1.72 & - & - \\
\hline 9.02 & $\beta$-Eudesmol & 0.26 & - & - \\
\hline 9.07 & $\gamma$-Eudesmol & - & 5.21 & - \\
\hline 9.11 & Hinesol & - & 2.03 & - \\
\hline 9.22 & a-Eudesmol & - & 12.93 & - \\
\hline 9.28 & Cis-1 (7), 8-p-mentha-diene-2-ol & - & 1.05 & - \\
\hline 9.38 & 5-Amino-1-phenylpyrazole & - & 1.15 & - \\
\hline 9.52 & $\begin{array}{l}\text { p-Cymene-3-propionic acid, } \\
\text { a-methyl }\end{array}$ & - & 0.35 & - \\
\hline 9.82 & 3-Carene, 4-isopropenyl & - & 0.34 & - \\
\hline 9.93 & Cis-Calemenene & - & 0.42 & - \\
\hline \multirow[t]{7}{*}{10.69} & Geranyl-a-Terpinene & - & 0.28 & - \\
\hline & Total & 96.84 & 98.92 & 99.98 \\
\hline & Hydrocarbons Monoterpene & 22.89 & 15.24 & 36.18 \\
\hline & Oxygenated Monoterpenes & 70.01 & 26.27 & 62.05 \\
\hline & Sesquiterpene Hydrocarbons & 0.20 & 30.53 & - \\
\hline & Oxygenated Sesquiterpenes & 0.84 & 24.90 & 1.75 \\
\hline & Others & 2.88 & 1.98 & - \\
\hline
\end{tabular}

was shaken thoroughly with a vortex machine and the absorbance was taken at $517 \mathrm{~nm}$. The volatile oil ability to scavenge DPPH free radical was calculated using the equation below

$$
\text { \%Inhibition } \left.=\left[\left(A_{\text {control }}-A_{\text {vo }}\right) / A_{\text {control }}\right)\right] \times 100
$$

where $\mathrm{A}_{\text {control }}$ is the absorbance of DPPH + DMSO; $\mathrm{A}_{\mathrm{vo}}$ is the absorbance of DPPH+ Volatile oil or the commercial antioxidant. The dose response curve was plotted and the $\mathrm{IC}_{50}$ value of the commercial antioxidant and volatile oil were calculated [21].

\section{ABTS assay}

The modified method of Witayapen [22] was used to evaluate the ABTS activity of the volatile oil extracts. The working solution was obtained by oxidation of ABTS stock solution $(7 \mathrm{mM})$ with $(2.4 \mathrm{mM})$ of potassium persulfate in equivalent amounts and the mixture was permitted to react for $12 \mathrm{~h}$ at $25^{\circ} \mathrm{C}$. A portion $(1 \mathrm{~mL})$ of the resultant solution 
was further diluted using $60 \mathrm{~mL}$ of methanol to obtain an absorbance of $0.706 \pm 0.001$ at $734 \mathrm{~nm}$ after $7 \mathrm{~min}$ using a UV-spectrophotometer. Summarily, five different concentrations $\left(0.025,0.05,0.1,0.2\right.$ and $\left.0.4 \mathrm{mgmL}^{-1}\right)$ of each of the volatile oils were mixed with methanolic solution of ABTS for $7 \mathrm{~min}$ at $25^{\circ} \mathrm{C}$ in the dark. The absorbance was then measured spectrophotometrically at $734 \mathrm{~nm}$ and the $\%$ inhibition of ABTS radical by the volatile oils and commercial antioxidants ( $\beta$-carotene \& Vitamin $C$ ) was calculated using the equation described for DPPH assay above.

\section{In vitro antibacterial action}

Antibacterial activity of the volatile oils was tested by means of the agar well diffusion method as described by Collin [23]. The microbial cultures used in this study were inoculated in nutrient broth (Oxoid) and incubated for $24 \mathrm{~h}$ at $37 \pm 0.1{ }^{\circ} \mathrm{C}$. Sufficient amount of Muller Hilton Agar (Oxoid) were poured into sterile petri dishes and permitted to solidify under aseptic situation. Using a sterilized cork borer, five $6 \mathrm{~mm}$ diameter wells were evenly distributed in freshly prepared and solidified Mueller Hilton agar (Oxoid) in petri dishes. The bacterial culture was adjusted to $0.5 \mathrm{Mc}$ Farland turbidity standard and the test microbes $(0.1 \mathrm{~mL})$ were inoculated with a germ-free swab on the exterior of the appropriate solid medium in each of the petri dishes. Varying concentrations of the volatile oil made from the stock ranging from 0.04 to $0.025 \mathrm{mgmL}^{-1}$ were prepared and introduced into each of the wells and labelled appropriately. The inoculated petri dishes were incubated at $37{ }^{\circ} \mathrm{C}$ for $24 \mathrm{~h}$. All the petri dishes were then examined for zones of growth inhibition surrounding the individual wells and the average diameter of these zones was measured in millimeters. All tests were performed under hygienic conditions.

\section{Separation of volatile oils}

Five hundred grams (500 g) of the leaves, two hundred and fifty grams $(250 \mathrm{~g})$ of the flowers and one hundred and fifty grams $(150 \mathrm{~g})$ of the stems of this plant were sequentially subjected to hydro- distillation process for three hours in Clevenger apparatus in accordance with the European Pharmacopoeia (2004) [24]. The volatile oil was consecutively extracted using $7 \mathrm{~L}, 4 \mathrm{~L}$ and $2 \mathrm{~L}$ of water. The oils collected from the various plant parts were immediately subjected to GC-MS analyses.

\section{Gas chromatography- mass spectrometry (GC-MS)}

GC-MS analyses were ran on a Hewlett-Packed HP 5973 mass spectrometer connected with an HP-6890 gas chromatograph. Operating conditions for this analyses were as followed: column temperature (original temperature) $-70{ }^{\circ} \mathrm{C}$, (highest temperature) $-240{ }^{\circ} \mathrm{C}$, (equilibration time) $-3 \mathrm{~min}$, (ramp) $-4{ }^{\circ} \mathrm{C} \mathrm{min}^{-1}$, (concluding temperature) $-240^{\circ}$ $\mathrm{C}$; inlet mode: split less, initial temperature $220^{\circ} \mathrm{C}$, pressure
$8.27 \mathrm{psi}$, flush out flow $30 \mathrm{~mL} / \mathrm{min}$, flush out time $0.20 \mathrm{~min}$, gas brand: helium, column: capillary, $30 \mathrm{~m} \times 0.25 \mathrm{~mm}$ i.d., coat thickness $0.25 \mu \mathrm{m}$, original flow $0.7 \mathrm{~mL} / \mathrm{min}$, linear velocity $32 \mathrm{~cm} / \mathrm{s}$; MS: EI method at $70 \mathrm{eV}$.

\section{Detection of components}

Chemical components of these oils were identified on the basis of their individual retention times with a reference to homologues series of n-alkanes in the robust NIST Library 2014. The mass spectra fragmentations of the compounds were compared to the available data [25-27].

Table 2 Major components of volatile oil of Callistemon citrinus from various part of the world

\begin{tabular}{|c|c|c|}
\hline Origin & Major Components & Reference \\
\hline South(f) Africa & $\begin{array}{l}\text { a-Eudesmol (12.93\%), } \\
\text { Caryophyllene (11.89\%), } \\
\text { Bornyl-acetate (10.02\%), } \\
\text { Eucalyptol (8.11\%), } \\
\text { Bicyclogermacrene (5.71\%) } \\
\text { and } \text {-Eudesmol (5.21\%). }\end{array}$ & This Present Study \\
\hline South(I) Africa & $\begin{array}{l}\text { Eucalyptol (48.98\%), } \\
\text { a-Pinene (20.02\%), } \\
\text { a-Terpineol (8.10\%), } \\
\text { Isopinocarveol (5.75\%) } \\
\text { and Pinocarvone (2.81\%). }\end{array}$ & This Present Study \\
\hline South(s) Africa & $\begin{array}{l}\text { Eucalyptol (56.00) and } \\
\text { a-Pinene (31.03). }\end{array}$ & This Present Study \\
\hline Himalaya(f) & $\begin{array}{l}\text { Eucalyptol (36.6\%), } \\
\text { a-Pinene }(29.7 \%)\end{array}$ & {$[37]$} \\
\hline Himalaya (I) & $\begin{array}{l}\text { a-Pinene }(32.30 \%), \\
\text { Limonene }(13.1 \%), \\
\text { a-Terpineol }(14.6 \%)\end{array}$ & {$[37]$} \\
\hline $\operatorname{Iran}(\mathrm{I})$ & $\begin{array}{l}\text { Eucalyptol (34.20\%), } \\
\text { a-Pinene (29.0\%), } \\
\text { a-Terpineol (16.70\%), } \\
\text { a-Phellandrene (9.0\%). }\end{array}$ & {$[38]$} \\
\hline \multirow[t]{2}{*}{ Iran } & $\begin{array}{l}\text { Eucalyptol }(67.60 \%), \\
\text { a-Pinene }(9.40 \%), \\
\beta \text {-Pinene }(4.70 \%)\end{array}$ & {$[39]$} \\
\hline & $\begin{array}{l}\text { a-Pinene }(25.70 \%), \\
\text { eucalyptol }(18.10 \%), \\
\text { B-Pinene }(7.30 \%), \\
\text { Linalool }(5.30 \%)\end{array}$ & [39] \\
\hline$(\mathrm{s})$ & $\begin{array}{l}\text { Eucalyptol (41.30\%), } \\
\text { a-Pinene (19.10\%), } \\
\text { a-Terpineol (4.10\%), }\end{array}$ & {$[39]$} \\
\hline Reunion Island (I) & $\begin{array}{l}\text { Eucalyptol (68.0\%), } \\
\text { a-Pinene (12.80\%), } \\
\text { a-Terpineol (10.6\%). }\end{array}$ & {$[40]$} \\
\hline $\begin{array}{l}\text { Lower(I) Region } \\
\text { of Himalaya }\end{array}$ & $\begin{array}{l}\text { Eucalyptol }(66.30 \%), \\
\text { a-Pinene }(18.70 \%)\end{array}$ & {$[41]$} \\
\hline South Africa (I) & $\begin{array}{l}\text { Eucalyptol (61.20\%), } \\
\text { a-Pinene (13.40\%), } \\
\beta \text {-Pinene (4.70\%) }\end{array}$ & {$[12]$} \\
\hline Pakistan & Eucalyptol $^{\mathrm{a}}, \mathrm{a}$-Terpineol ${ }^{\mathrm{a}}$ & {$[42]$} \\
\hline
\end{tabular}

I leaves, $f$ flowers, $s$ stems, ${ }^{a}$ Quantitative data not available 


\section{Statistical analysis}

Statistical analyses were carried out using Microsoft Excel 2007.

\section{Results \\ Discussion \\ Constituents of the volatile oils}

Hydro distillation of the leaves, flowers and stems of Callistemon citrinus produced a clear light, pale yellow and light oil with percentage yields of $0.70 \%$ (leaves), $0.80 \%$ (flowers) and $0.50 \%$ (stems) $v / w$ of the wet samples. The identified components, retention times and percentage compositions of the chemical compounds are given in Table 1 above. From the table it is obvious that qualitative and quantitative constituents of the oils are different from each other.

Twenty-six components for the leaves oil amounting to $96.84 \%$, forty-one components for the flowers oil representing $98.92 \%$ and ten components for the stems oil amounting to $99.98 \%$ were identified in the three oil samples. The leaves oil was composed of mainly oxygenated monoterpenes $(70.01 \%)$, followed by monoterpene hydrocarbons (22.89\%), sesquiterpene hydrocarbon (0.20\%), and oxygenated sesquiterpenes $(0.84 \%)$. The dominant constituents in the leaves oil samples were eucalyptol (48.98\%), $\alpha$-Pinene (20.02\%), $\alpha$-terpineol (8.01\%) and pinocarveol (5.75\%). Other notable components found were Pinocarvone $(2.81 \%)$ and $\beta$-pinene (1.10\%). Minor constituents include $\alpha$-fenchol $(0.93 \%)$, terpinen-4-ol (0.79\%), camphene $(0.63 \%)$ and $\beta$-linalool (0.57\%).

The flower oil was found rich in sesquiterpene hydrocarbons $(30.53 \%)$, followed by oxygenated monoterpenes (26.27\%), oxygenated sesquiterpenes (24.90\%) and monoterpenes hydrocarbon (15.24\%). The main constituents characterizing the floral oil were $\alpha$-eudesmol (12.93\%), caryophyllene (11.89\%), (-)-bornyl acetate
(10.02\%), eucalyptol (8.11\%), bicyclogermacrene (5.71\%), $\gamma$-eudesmol (5.21\%) and 1R- $\alpha$-Pinene (4.57\%).

Similarly, the stem oil comprises of oxygenated monoterpenes $(62.05 \%)$ and monoterpene hydrocarbons (36.18\%). The key components dominating the stem oil were eucalyptol (56.00\%), $\alpha$-pinene (31.03\%), limonene (3.97\%) and $\alpha$-terpineol (3.69\%).

The various components of volatile oil have been associated with different therapeutic activities. Eucalyptol, which is the chief constituents of both leaves and stems oils of Callistemon citrinus in addition to its anti-inflammatory activity possesses notable antiviral activity, antitussive, bronchodilator, mucolytic and mucociliary effects. It also has positive activity on the lung function for the ordinary cold or persistent obstructive pulmonary ailment [28]. It also possesses bacteriostatic and bactericidal activity [29].

$\alpha$-pinene which ranks as the next key constituent of the leaves oil in this work reportedly has biological activity with broad spectrum that is anti-inflammatory [30], antibacterial [31], antioxidant [32], anticancer [33] and antinociceptive [34]. Due to these properties stated above the plant has been found useful in the traditional management of some infectious diseases caused by bacteria, fungi and virus. It is also used in the treatment of bronchitis and respiratory conditions like cough.

The flower volatile oil of our sample has $\alpha$-Eudesmol as the major component. It does show high voltage-gate calcium channel blocker activity, which is a foremost problem in anti-migraine treatment [35] and is available to attenuate post-ischemic brain injury in rats [36].

Volatile oil of the leaves of Callistemon citrinus in this study showed similar profile compared to those reported earlier in literature as shown in (Table 2) above [12, 37-42]. Eucalyptol was found to be the main constituent though in varying amount except for Himalaya where the dominant component of the leaves oil was $\alpha$-pinene (32.30\%) but the

Table 3 Inhibition zone $(\mathrm{mm})$ showing antibacterial activities of volatile oils and ciprofloxacin against bacterial test organisms

\begin{tabular}{|c|c|c|c|c|c|c|c|c|c|}
\hline \multirow{3}{*}{$\begin{array}{l}\text { Microorganism } \\
\text { Concentration }\end{array}$} & \multirow{2}{*}{\multicolumn{3}{|c|}{$\frac{\text { Positive control }}{\text { Ciprofloxacin }\left(\mathrm{mgmL}^{-1}\right)}$}} & \multicolumn{6}{|c|}{ Zone of inhibition of volatile oils and standard drug } \\
\hline & & & & \multicolumn{3}{|c|}{ Leaves volatile oil $\left(\mathrm{mgmL}^{-1}\right)$} & \multicolumn{3}{|c|}{ Flowers volatile oil $\left(\mathrm{mgmL}^{-1}\right)$} \\
\hline & 0.4 & 0.1 & 0.025 & 0.4 & 0.1 & 0.025 & 0.4 & 0.1 & 0.025 \\
\hline \multicolumn{10}{|l|}{ Gram negative Bacteria } \\
\hline Aeromonas hydrophilia ACC & $34.0 \pm 0.6$ & $26.0 \pm 2.0$ & $20.0 \pm 0.5$ & $58.0 \pm 0.3$ & $44.0 \pm 4.0$ & $19.0 \pm 0.6$ & $52.0 \pm 1.0$ & $41.0 \pm 1.0$ & $15.0 \pm 0.8$ \\
\hline Escherichia coli ATCC 35150 & $38.0 \pm 4.0$ & $32.0 \pm 4.0$ & $24.0 \pm 0.9$ & $27.0 \pm 3.0$ & $18.0 \pm 3.0$ & $13.0 \pm 3.0$ & $20.0 \pm 4.0$ & $12.0 \pm 4.0$ & $10.0 \pm 3.0$ \\
\hline Vibro alginolyticus DSM 2171 & $33.0 \pm 2.0$ & $29.0 \pm 2.0$ & $23.0 \pm 0.4$ & $67.0 \pm 2.0$ & $48.0 \pm 5.0$ & $28.0 \pm 4.0$ & $60.0 \pm 5.0$ & $42.0 \pm 0.8$ & $23.0 \pm 1.0$ \\
\hline Salmonella typhi ACC & $40.0 \pm 1.0$ & $34.0 \pm 0.6$ & $28.0 \pm 3.0$ & $53.0 \pm 0.5$ & $40.0 \pm 1.0$ & $20.0 \pm 2.0$ & $48.0 \pm 0.5$ & $35.0 \pm 2.0$ & $14.0 \pm 0.5$ \\
\hline \multicolumn{10}{|l|}{ Gram positive Bacteria } \\
\hline Staphylococcal enteritis ACC & $40.0 \pm 5.0$ & $32.0 \pm 1.0$ & $28.0 \pm 0.2$ & $62.0 \pm 0.5$ & $45.0 \pm 0.1$ & $25.0 \pm 0.4$ & $55.0 \pm 2.0$ & $38.0 \pm 0.9$ & $22.0 \pm 0.9$ \\
\hline Staphylococcus aureus ACC & $29.0 \pm 2.0$ & $24.0 \pm 0.0$ & $17.0 \pm 2.0$ & $54.0 \pm 4.0$ & $26.0 \pm 1.0$ & $18.0 \pm 2.0$ & $53.0 \pm 3.0$ & $24.0 \pm 5.0$ & $16.0 \pm 2.0$ \\
\hline Listeria monocytogenes ACC & $44.0 \pm 6.0$ & $38.0 \pm 0.2$ & $32.0 \pm 1.0$ & $54.0 \pm 2.0$ & $42.0 \pm 2.0$ & $21.0 \pm 1.0$ & $50.0 \pm 2.0$ & $39.0 \pm 3.0$ & $18.0 \pm 3.0$ \\
\hline
\end{tabular}


flowers oil from this region was still eucalyptol. This could be attributed to environmental factors like variable ecological and climatic conditions in the regions, as well as the nature of the plant and the processing method [43].

$\alpha$ - eudesmol (12.93\%), caryophyllene (11.89\%) and bornyl acetate (10.02\%) were the dominant components found in the volatile oil of the flowers of this plant under investigation. Eucalyptol was also notably present in the flower oil but the content was low (8.11\%) compared to the stems and leaves oils which were $(56.00 \%)$ and (48.98\%) respectively. The oil collected from the flowers shows no homogeneity in constituents in comparison with others in the literature (Table 2). While the flowers essential oil from Iran showed $\alpha$-pinene $(25.70 \%)$ and eucalyptol (18.10\%) as the principal components [39], another from Himalaya recorded eucalyptol (36.60\%) and $\alpha$-pinene (29.70\%) as its foremost components [37]. The present study reveals that $\alpha$ - eudesmol (12.93\%), caryophyllene $(11.89 \%)$ and bornyl acetate $(10.02 \%)$ are the major constituents in the flower oil. This might be related to the effects of several factors like relative humidity, irradiance, photoperiod, method of extraction, plant cultivation techniques, soil structure and climate which could greatly influence the composition and quality of essential oil [44].

\section{Overall phenolic content (Opc)}

The overall phenolic content in the leaves volatile oil was found to be $899.00 \mu \mathrm{gmg}^{-1}$ gallic acid equivalent, which was higher than the same species from India that recorded $261 \mathrm{mg} / \mathrm{g}$ [45]. This shows the presence of phenolic compounds such as $\alpha$-terpineol and pinocarveol in the leaves oil. Phenolic compounds in plants are known to increase its antioxidant activity [46]. They have a major responsibility in scavenging free radicals that cause oxidative stress due to their antioxidant capacity against peroxyl radicals. This helps them scavenge electrophiles and active oxygen species, limit auto-oxidation by chelating metal ions and increase the ability to adjust some enzymes action [47].

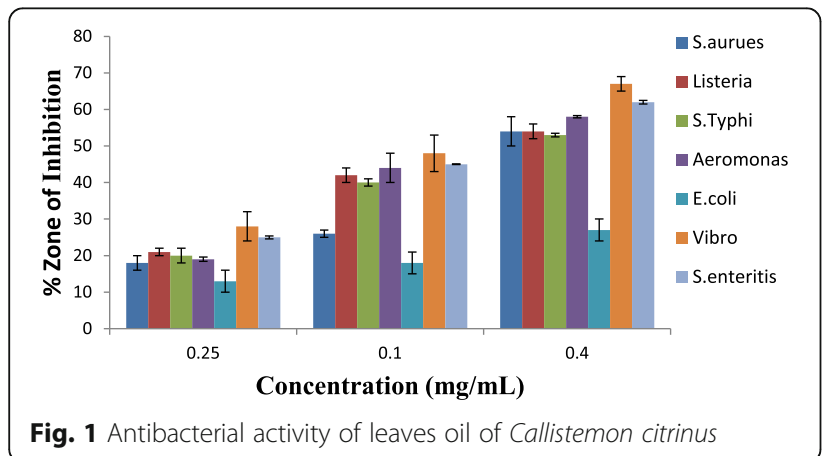

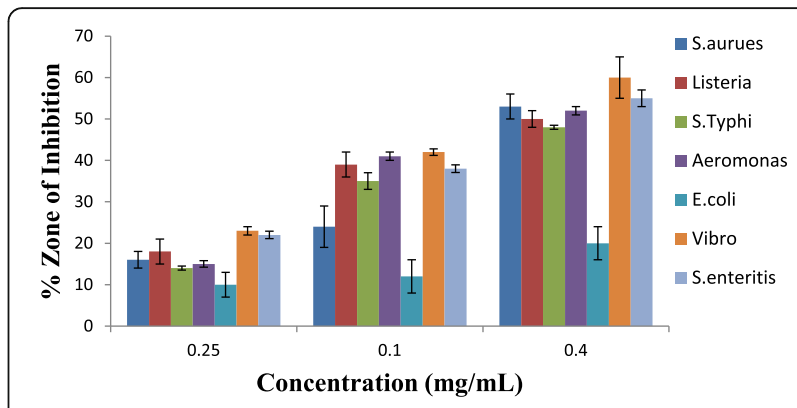

Fig. 2 Antibacterial activity of flower oil of Callistemon citrinus

\section{Antibacterial activities of the leaves and flowers volatile oil}

The present work examined the in-vitro antibacterial activities of the volatile oils from leaves and flowers of Callistemon citrinus on the four gram negative and three gram positive bacteria as shown in (Table 3). The activities of the oils in terms of inhibitory zones were effective on all the tested bacteria showing that the plant under study has very wide spectrum of action against both gram positive and gram negative bacteria (Figs. 1 \& 2). The inhibitory effect of both the leaves and flowers oils was highest against gram negative bacteria like Vibro alginolyticus DSM 2171 $(67 \pm 2.0 \& 60 \pm 5.0 \mathrm{~mm})$ and Aeromonas hydrophila ACC (58 $\pm 0.3 \& 52 \pm 1.0 \mathrm{~mm}$ ), as well as the gram positive bacteria such as Staphylococcal enteritis ACC $(62 \pm 0.5$ \& $55 \pm 2.0 \mathrm{~mm})$ at a concentration of $0.4 \mathrm{mg} / \mathrm{mL}$, while the lowest effect was recorded for E.coli ATCC $35150(27 \pm 3.0$ \& $20 \pm 4.0 \mathrm{~mm})$. Both the leaves and flowers oil showed highest inhibitory effect on gram negative bacteria which was contrary to some reports published in literature [48]. The antibacterial properties of these volatile oils were found comparable to that of the leaves volatile oil from Western part of South Africa which gave inhibition zone ranging between 13.3 and $26.3 \mathrm{~mm}$ for S. aureus (ATCC 3983), a gram positive bacteria, also E.coli (ATCC 4983) and $P$. aeruginosa (ATCC 7700) which are gram negative bacteria [12]. The antibacterial effect observed in this plant may be linked to some bioactive compounds such as alkaloids, tannins, terpenoids, ether and phenolic compounds like flavonoids, which are considered to be bacteriostatic and

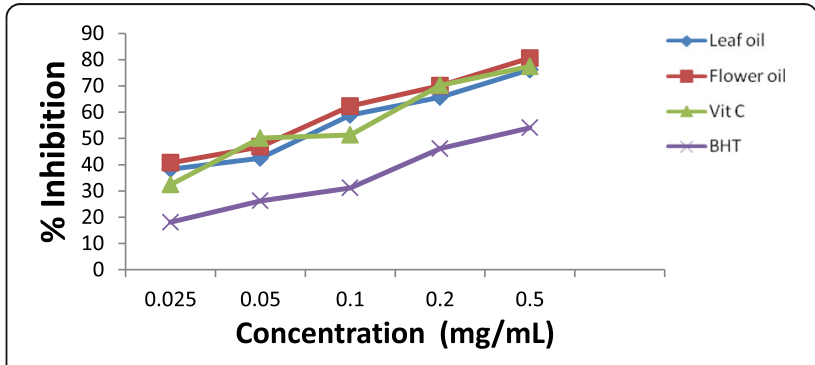

Fig. 3 DPPH scavenging action 
Table $4 \mid C_{50}$ profile of the leaves and flowers oil of Callistemon citrinus $\left(\mathrm{mgmL}^{-1}\right)$

\begin{tabular}{|c|c|c|c|c|c|c|}
\hline \multirow[b]{2}{*}{$\mathrm{S} / \mathrm{N}$} & \multirow[b]{2}{*}{ Activity } & \multicolumn{2}{|c|}{ Callistemon citrinus } & \multicolumn{2}{|c|}{$\begin{array}{l}\text { Standard Antioxidant } \\
\text { (Positive control) }\end{array}$} & \multirow[b]{2}{*}{$\begin{array}{l}\mathrm{BHT} \\
\left(\mathrm{IC}_{50}\right)\end{array}$} \\
\hline & & $\begin{array}{l}\text { Leaves } \\
\text { oil }\left(\mathrm{IC}_{50}\right)\end{array}$ & $\begin{array}{l}\text { Flowers } \\
\text { oil }\left(\mathrm{IC}_{50}\right) \\
\end{array}$ & $\begin{array}{l}\text { Vitamin } \\
\mathrm{C}\left(\mathrm{I}_{50}\right)\end{array}$ & $\begin{array}{l}\beta \text {-Carotene } \\
\left(\mathrm{I}_{50}\right)\end{array}$ & \\
\hline 1 & DPPH & 1.49 & 1.13 & 3.57 & 1.28 & - \\
\hline 2 & ABTS & 0.14 & 0.03 & 0.13 & - & 0.19 \\
\hline
\end{tabular}

DPPH 2,2-diphenylpicrylhydrazyl radicals, $A B T S$ 2,2'-azino-bis diammonium salt, BHT Butylated hydroxyl toluene

fungistatic $[49,50]$. This effect correlates with its folkloric uses and shows that it is an efficient antimicrobial plant that can be employed in alternative medicine for the treatment of bacterial infection [51].

\section{In-vitro antioxidant action}

The in-vitro antioxidant activities of the volatile oils were evaluated using DPPH radical scavenging test. The violet colour production of $\mathrm{DPPH}$ dissolved in DMSO is due to its unpaired nitrogen electrons. The DPPH radical is in the process reduced to $\mathrm{DPPH}-\mathrm{H}$, turning from violet to yellow in the presence of antioxidant compound [52].

The inhibition of the DPPH radical by the volatile oil of the leaves and flowers was concentration dependent. The inhibition percentage of the volatile oils at different concentrations $\left(0.025,0.05,0.1,0.2,0.4 \mathrm{mgmL}^{-1}\right)$ ranged between $38.3 \%$ and $76.2 \%$ for the leaves oil and from $40.7 \%$ to $80.6 \%$ for the flowers oil. In the same vein, the percentage of inhibition for both the ascorbic acid and $\beta$-carotene varied as $18.1 \%-54.04 \%$ and $32.4 \%-77.45 \%$ respectively (Fig. 3). The leaves and the flowers oils were capable of reducing the DPPH radical by $50 \%$ with $\mathrm{IC}_{50}$ of 1.49 and $1.13 \mathrm{mgmL}^{-1}$ compared to $\beta$-carotene and ascorbic acid which have an $\mathrm{IC}_{50}$ of 1.28 and 3.57 $\mathrm{mgmL}^{-1}$ (Table 4). The capacity of the DPPH radical scavenging of the flowers oil in terms of percentage inhibition and $\mathrm{IC}_{50}$ was higher than those of the leaves oil and the two synthetic antioxidant drugs. The inhibition of DPPH free radical by both the leaves and flowers oils were higher than that reported for the volatile oil of same species in Iran [39]. For the ABTS assay, the essential oils collected from the leaves and flowers of the plant under study showed free radical scavenging activities which were dose dependent, having a maximum activity of $79.47 \%$ at $0.4 \mathrm{mgmL}^{-1}$ for the leaves oil and 95.61\% for the flowers oils (Fig. 4). The oils from both plant parts showed a $50 \%$ reduction of 0.14 and 0.03 $\mathrm{mgmL}^{-1}$ respectively which implies that the flowers oil possesses higher antioxidant capacity than the leaves oil and other typical antioxidants (Vitamin C \& BHT) with $\mathrm{IC}_{50}$ of 0.13 and 0.19 respectively (Table 4 ). The high scavenging activity of the leaves oil over BHT (standard antioxidant) could be due to the high content of Eucalyptol in the leaves oil [53].

The antioxidant activities of volatile oils are reportedly not only due to phenolic content of the oil but also some other constituents like monoterpene alcohol, ketone, aldehyde, hydrocarbons and ethers which are known to contribute to the free radical scavenging activity of some volatile oil [54]. Volatile oils of Thymus caespititus, Thyme camphorates, and Thyme mastichina which contain high contents of linalool and eucalyptol were found with high antioxidant activities which were almost equal to that of $\alpha$-tocopherol [55]. Similarly, the M. aquatic high scavenging activity was due to the presence of eucalyptol in the volatile oil [53]. The essential oil of the plant in the present study also showed high level of eucalyptol (monoterpenoid ether) which might be responsible for its antioxidant activity.

\section{Conclusion}

This study represents the first analyses of the volatile constituents of the essential oils from Callistemon citrinus leaves, flowers and stem to the best of my knowledge in the Eastern Province of South Africa. Aside from the traditional uses of the extract of the plant, its

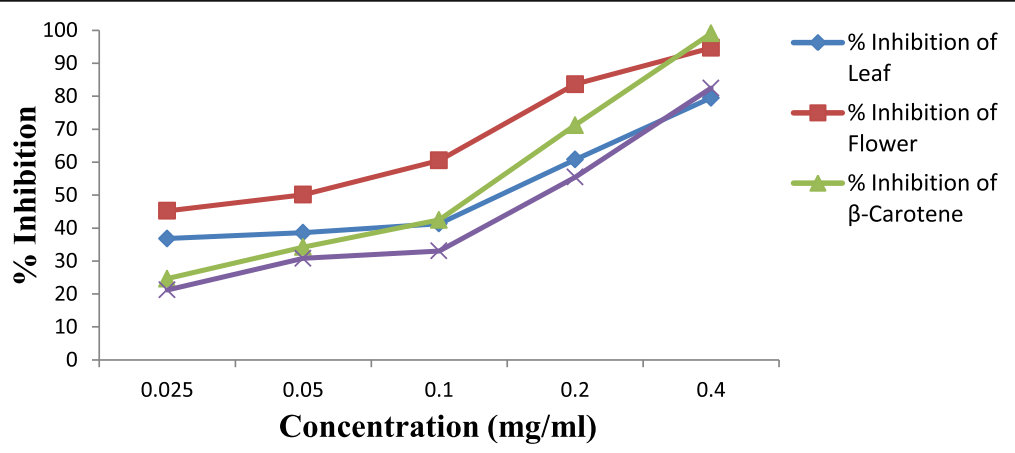

Fig. 4 ABTS scavenging action 
volatile oil possesses high-quality antioxidant potential and may possibly compete well with synthetic antioxidant drugs in the market. Observation drawn from this experiment shows clearly that the leaves and flowers of Callistemon citrinus possess substantial quantity of the phenolic compounds and cyclic ether with several pharmacological behaviors. The present investigation showed that the studied plant is a good traditional herb of potential value for the cure of various ailments.

\begin{abstract}
Abbreviations
ABTS $^{*+}$ : 2, 2-azinobis-(3-ethylbenzothiazolin-6-sulfonic acid) diammonium salt radical; ACC: AEMREG culture collection; ATCC: American type collection center; BHT: Butylated hydroxyl toluene; DMSO: Dimethyl sulphur oxide; $\mathrm{DPPH}^{*}$ : 2, 2-diphenyl-1-picrylhydrazyl; f: flowers; GC-MS: Gas chromatography-mass spectrometry; $I C_{50}$ : Inhibitory concentration at 50\%; I: leaves; OPC: Overall phenolic content; PPS: Potassium persulfate; s: stems
\end{abstract}

\section{Acknowledgements}

Applied and Environmental Microbial Research Group (AEMREG) University of Fort Hare South Africa are appreciated for the antimicrobial analysis, GMRDC South Africa and Kogi State University, Anyigba Nigeria are also appreciated for their Financial Support.

\section{Availability of data and materials}

All data and materials used in this study are in the manuscript as well as in the supporting files attached.

\section{Authors' contributions}

LR carried out the experimental part such as collection of samples, analysis of the volatile oil, antioxidant assay while antimicrobial activity was carried out in AEMREG laboratory, OOO and SA helped in supervising the analysis of the results, $\mathrm{AlO}$ assisted in coordinating the research and the preparation of the manuscript. All authors read and agreed on the final manuscript.

\section{Authors' information}

LR is a Ph.D., student (Natural Product Section) in the department of Chemistry, University of Fort Hare, $\mathrm{OOO}$ is an Associate Professor of pure and Analytical Chemistry, University of Fort Hare, SA is a Professor of Physical Chemistry, University of Fort Hare, and AIO is a Professor of Microbiology, University of Fort Hare. Apart from LR, $\mathrm{OOO}$ is my Supervisor and others Co-supervisors.

\section{Competing interests}

The author(s) assert that they have no opposing interests.

\section{Consent for publication}

All authors mentioned agreed for the publication of the manuscript.

\section{Ethics approval and consent to participate}

Not Applicable in this study.

\section{Publisher's Note}

Springer Nature remains neutral with regard to jurisdictional claims in published maps and institutional affiliations.

\section{Author details}

'Department of Pure and Applied Chemistry, University of Fort Hare, Alice 5700 , South Africa. ${ }^{2}$ Chemistry Department, Kogi State University, Anyigba, Kogi, Nigeria. ${ }^{3}$ SAMRC Microbial Water Quality Monitoring Center, University of Fort Hare, Alice, Eastern Cape, South Africa. ${ }^{4}$ Applied and Environmental Microbiology Research Group (AEMREG), Department of Biochemistry and Microbiology, University of Fort Hare, Alice, Eastern Cape, South Africa.
Received: 13 February 2017 Accepted: 23 May 2017

Published online: 05 June 2017

\section{References}

1. Yadav RN, Agarwala M. Phytochemical analysis of some medicinal plants. Journal of phytology. 2011; 3(12).

2. Khanna RK, Sharma OS, Singh A. Essential oil from the leaves of Callestemon polandii FM bailey. Indian Perfumer. 1990;34(2):123-5.

3. Gilman EF. Callistemon rigidus1. Inst of Food and Agricultural Sciences: Environmental Horticulture Department; 1999.

4. Nel JL, Richardson DM, Rouget M, Mgidi TN, Mdzeke N, Le Maitre DC, et al. A proposed classification of invasive alien plant species in South Africa: towards prioritizing species and areas for management action: working for water. S Afr J Sci. 2004;100(1-2):53-64.

5. Spencer RD, Lumley PF. Callistemon. Flora of new South Wales. 1991:168-73.

6. Wrigley JW, Fagg M. Bottlebrushes, paperbarks and tea trees: and all other plants in the Leptospermum alliance. Sydney: Angus \& Robertson xiii, 352p.illus., col. illus.. ISBN. 1993; 207168679.

7. Chopra RN, Nayer SL, Chopra IC. Glossary of Inidan Medicinal plants CSIR, New Delhi. J71. 1956; 34

8. Wrigley JW, Fagg M. Australian native plants. Concise ed. Chatswood, NWS, Australia: New Holland Publishers; 2007.

9. Goyal PK, Jain R, Jain S, Sharma A. A Review on biological and phytochemical investigation of plant genus Callistimon. Asian Pacific Journal of Tropical Biomedicine. 2012; 1; 2(3):S1906-9.

10. Shaha A, Salunkhe VR. Development and validation of a high performance thin layer chromatographic method for determination of 1, 8-cineole in Callistemon Citrinus. Pharm res. 2014;6(2):143.

11. Netala SI, Penmetsa RE, Nakka SN, Polisetty BL. Pharmacognostic study of Callistemon citrinus L. bark. Int J Pharm Pharm Sci. 2015;7(1):427-30.

12. Oyedeji OO, Lawal OA, Shode FO, Oyedeji AO. Chemical composition and antibacterial activity of the essential oils of Callistemon Citrinus and Callistemon viminalis from South Africa. Molecules. 2009:14(6):1990-8.

13. Sudhakar M, Rao CV, Rao AL, Ramesh A, Srinivas N, Raju DB, et al. Antinociceptive and anti-inflammatory effects of the standardized oil of Indian Callistemon lanceolatus leaves in experimental animals. East and Central African Journal of Pharmaceutical Sciences. 2004:7(1):10-5.

14. Sadlon AE, Lamson DW. Immune-modifying and antimicrobial effects of Eucalyptus oil and simple inhalation devices. Altern med rev. 2010;15(1):33-43.

15. Small BE. The Australian eucalyptus oil industry -an overview. Aust for. 1981:44(3):170-7.

16. Jennings WC. Isolement et caractérisation des composés responsables de la flaveur. Indus Aliment Agr. 1970;

17. Burt S. Essential oils: their antibacterial properties and potential applications in foods - a review. Int J Food Microbiol. 2004;94(3):223-53.

18. Hulin V, Mathot AG, Mafart P, Dufosse L. Les proprietés anti-microbiennes des huiles essentielles et composés d'arômes. Sci Aliment. 1998;18(6):563-82.

19. Jirovetz L, Buchbauer G, Denkova Z, Stoyanova A, Murgov I, Schmidt E, et al. Antimicrobial testings and gas chromatographic analysis of pure oxygenated monoterpenes 1, 8-cineole, a-terpineol, terpinen-4-ol and camphor as well as target compounds in essential oils of pine (Pinus pinaster), rosemary (Rosmarinus officinalis), tea tree (Melaleuca alternifolia). Sci Pharm. 2005;73(1):27-38.

20. Govindappa M, Poojashri MN. Antimicrobial, antioxidant and in vitro antiinflammatory activity of ethanol extract and active phytochemical screening of Wedelia trilobata (L.) Hitchc. J Pharmacogn Phytother. 2011;3(3):43-51.

21. Okoh SO, Asekun OT, Familoni OB, Afolayan AJ. Composition and antioxidant activities of leaf and root volatile oils of Morinda Lucida. Nat Prod Commun. 2011:10:1537-41.

22. Nantitanon W, Chowwanapoonpohn S, Okonogi S. Antioxidant and antimicrobial activities of Hyptis suaveolens essential oil. Sci Pharm. 2007; 75(1):35-54.

23. Collins CH., Lyne PM., Grange JM. and Falkinham III, JO. Microbiological Methods. $8^{\text {th }}$ Edition. Butterworth and Co. Ltd. 2004; 168-186.

24. European Pharmacopoeia Commission. European Pharmacopoeia. $5^{\text {th }}$ Ed. Council of Europe: Strasbourg Cedex, France. 2004

25. McLafferty FW. Stauffer DB. The Wiley/NBS registry of mass spectral data: Wiley-Interscience; 1989

26. Adams, RP. Identification of Essential Oil Components by gas chromatography/quadrupole mass spectroscopy. ion trap mass spectroscopy. Allured Publishing Corporation, Illinois, USA. 2001; P.456. 
27. Joulain D, König WA. The atlas of spectral data of sesquiterpene hydrocarbons. EB-Verlag; 1998.

28. Harris B. 1, 8 cineole-a component of choice for respiratory pathologies International Journal of Clinical Aromatherapy Vol4 (2). 2007:3-8.

29. Soković M, Glamočlija J, Marin PD, Brkić D, van Griensven LJ. Antibacterial effects of the essential oils of commonly consumed medicinal herbs using an in vitro model. Molecules. 2010;15(11):7532-46.

30. Bae GS, Park KC, Choi SB, Jo IJ, Choi MO, Hong SH, et al. Protective effects of alpha-pinene in mice with cerulein-induced acute pancreatitis. Life Sci. 2012;91(17):866-71.

31. Dorman HJ, Figueiredo AC, Barroso JG, Deans SG. In vitro evaluation of antioxidant activity of essential oils and their components. Flavour and Fragrance Journal. 2000;15(1):12-6.

32. Wang W, Wu N, Zu YG, Fu YJ. Antioxidative activity of Rosmarinus officinalis L. essential oil compared to its main components. Food Chem. 2008;108(3):1019-22.

33. Wang W, Li N, Luo M, Zu Y, Efferth T. Antibacterial activity and anticancer activity of Rosmarinus officinalis $L$. essential oil compared to that of its main components. Molecules. 2012;17(3):2704-13.

34. Him A, Ozbek H, Turel I, Oner AC. Antinociceptive activity of alpha-pinene and fenchone. Pharmacol Online. 2008;3:363-9.

35. Asakura K, Kanemasa T, Minagawa K, Kagawa K, Yagami T, Nakajima M, et al. a-Eudesmol, a P/Q-type ca 2+ channel blocker, inhibits neurogenic vasodilation and extravasation following electrical stimulation of trigeminal ganglion. Brain res. 2000;873(1):94-10.

36. Asakura K, Matsuo Y, Oshima T, Kihara T, Minagawa K, Araki Y, et al. $\omega$ Agatoxin IVA-sensitive ca 2+ channel blocker, a-eudesmol, protects against brain injury after focal ischemia in rats. Eur J Pharmacol. 2000;394(1):57-65.

37. Kumar D, Sukapaka M, Babu GK, Padwad Y. Chemical composition and in vitro cytotoxicity of essential oils from leaves and flowers of Callistemon Citrinus from western himalayas. PLoS One. 2015;10(8):e0133823.

38. Zandi-Sohani N, Hojjati M, Carbonell-Barrachina AA. Volatile composition of the essential oil of Callistemon Citrinus leaves from Iran. Journal of Essential oil Bearing Plants. 2012;15(5):703-7.

39. Minar.J; Amineh. K.; Abol Fazi. DT and Fariba. R. Essential oil composition and antioxidant activity of hydromethanolic extract from the flowers, leaves and stems of Callistemon citrinus (Curtis) skeels. Indian Journal of natural Products and Resources Vol 5 (4), 2014; 308-312.

40. Chane-Ming J, Vera RR, Fraisse DJ. Chemical composition of essential oil of Callistemon Citrinus (Curtis) Skeel from Reunion. J Essent oil res. 1998;10(4):429-31.

41. Srivastava SK, Ahmad A, Syamsunder KV, Aggarwal KK, Khanuja SP. Essential oil composition of Callistemon viminalis leaves from India. Flavour and Fragrance Journal. 2003;18(5):361-3.

42. Riaz M, Chaudhary FM. The chemical composition of Pakistani Callistemon Citrinus oils. J Essent oil res. 1990;2(6):327-8

43. Ogundajo AL, Oladosu IA, Ogunwande IA, Flamini G, Owolabi MS. Study on the volatile constituents of Solanum nigrum L. var virginicum from Nigeria. Asian J Plant Sci res. 2013;3(1):94-8.

44. Panizzi L, Flamini G, Coni PL, Morelli I. Composition and antimicrobial properties of essential oils of four Mediterranean Laminaceae. J Ethnopharmacol. 1993;39:167-70.

45. Kumar A, Kaur R, Thind TS, Arora R, Kaur P, Arora S. In vitro Antioxidative potential of extracts from Callistemon lanceolatus sweet. And Eucalyptus Lanceolata Labill. Int. J. Curr. Microbiol. App. Sci. 2015:4(10):316-24.

46. Tawata S, Taira S, Kobamoto N, Ishihara M, Toyama S. Syntheses and biological activities of dihydro-5, 6-dehydrokawain derivatives. Biosci Biotechnol Biochem. 1996;60(10):1643-5.

47. Mediani A, Abas F, Khatib A, Tan CP. Cosmos caudatus As a potential source of polyphenolic compounds: optimisation of oven drying conditions and characterisation of its functional properties. Molecules. 2013;18(9):10452-64.

48. Cock IE. Antimicrobial activity of Callistemon Citrinus and Callistemon salignus methanolic extracts. 2012 Pharmacognosy. Communications. 2012;2(3):50-7.

49. Okwu DE, Iroabuchi Fl. Phytochemical studies and antimicrobial activity screening of aqueous and ethanolic roots extracts of Uvaria chamae bear and Cnestis ferruginea DCJ Chem. Soc Nig. 2001;29(2):112-4.

50. Okwu DE, Morah FN. Isolation and characterization of flavanone glycoside 4l, 5, 7-trihydroxy flavanone rhamnoglucose from Garcinia kola seed. J Appl Sci. 2007;7:306-9.

51. Doughari JH, Human IS, Bennade S, Ndakidemi PA. Phytochemicals as chemotherapeutic agents and antioxidants: possible solution to the control of antibiotic resistant verocytotoxin producing bacteria. Journal of Medicinal Plants Research. 2009;3(11):839-48.
52. Edziri H, Ammar S, Soulad L, Mahjoub MA, Mastouri M, Aounim MZ, et al. In vitro evaluation of antimicrobial and antioxidant activities of some Tunisians vegetables. S.Afri. Bot. 2012;78:252-6.

53. Mimica-Dukić N, Božin B, Soković M, Mihajlović B, Matavulj M. Antimicrobial and antioxidant activities of three Mentha species essential oils. Planta med. 2003;69(05):413-9.

54. Edris AE. Pharmaceutical and therapeutic potentials of essential oils and their individual volatile constituents: a review. Phytother res. 2007;21(4):308-23.

55. Miguel G, Simoes M, Figueiredo AC, Barroso JG, Pedro LG, Carvalho L. Composition and antioxidant activities of the essential oils of Thymus caespititius, Thymus camphoratus and Thymus mastichina. Food Chem. 2004;86(2):183-8.

\section{Submit your next manuscript to BioMed Central and we will help you at every step:}

- We accept pre-submission inquiries

- Our selector tool helps you to find the most relevant journal

- We provide round the clock customer support

- Convenient online submission

- Thorough peer review

- Inclusion in PubMed and all major indexing services

- Maximum visibility for your research

Submit your manuscript at www.biomedcentral.com/submit
) Biomed Central 